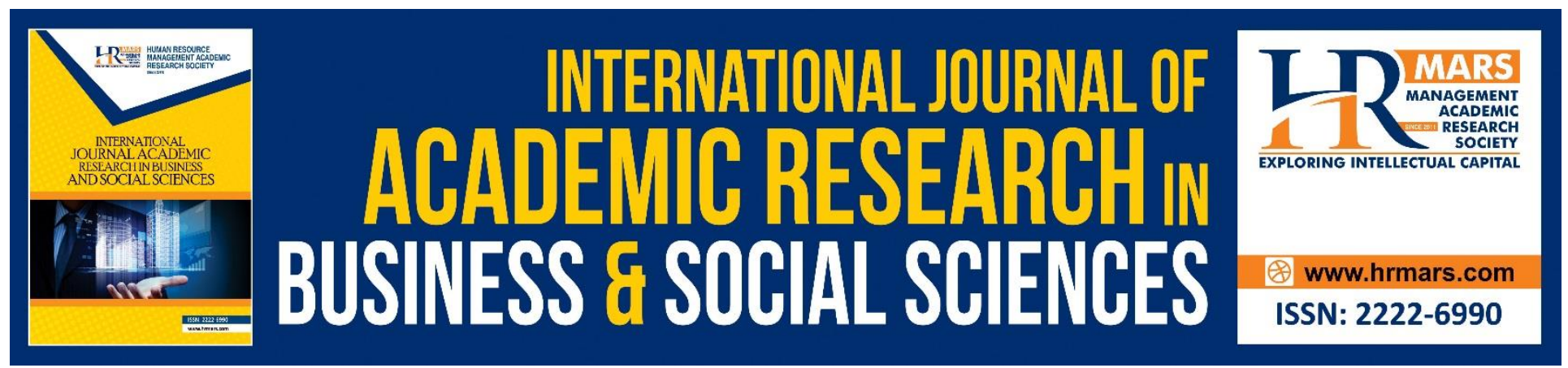

\title{
Influence of Project Supervision on Performance of Road Construction Projects, Uasin Gishu County
}

Rachel Wangoi Kimingi, Jacob Olango

To Link this Article: http://dx.doi.org/10.6007/IJARBSS/v10-i11/8093

DOI:10.6007/IJARBSS/v10-i11/8093

Received: 09 September 2020, Revised: 29 September 2020, Accepted: 14 October 2020

Published Online: 18 November 2020

In-Text Citation: (Kimingi, \& Olango, 2020)

To Cite this Article: Kimingi, R. W., \& Olango, J. (2020). Influence of Project Supervision on Performance of Road Construction Projects, Uasin Gishu County. International Journal of Academic Research in Business and Social Sciences. 10(11), 347-359.

Copyright: (c) 2020 The Author(s)

Published by Human Resource Management Academic Research Society (www.hrmars.com)

This article is published under the Creative Commons Attribution (CC BY 4.0) license. Anyone may reproduce, distribute, translate and create derivative works of this article (for both commercial and non-commercial purposes), subject to full attribution to the original publication and authors. The full terms of this license may be seen

at: http://creativecommons.org/licences/by/4.0/legalcode

Vol. 10, No. 11, 2020, Pg. 347 - 359

http://hrmars.com/index.php/pages/detail/IJARBSS

JOURNAL HOMEPAGE

Full Terms \& Conditions of access and use can be found at http://hrmars.com/index.php/pages/detail/publication-ethics 


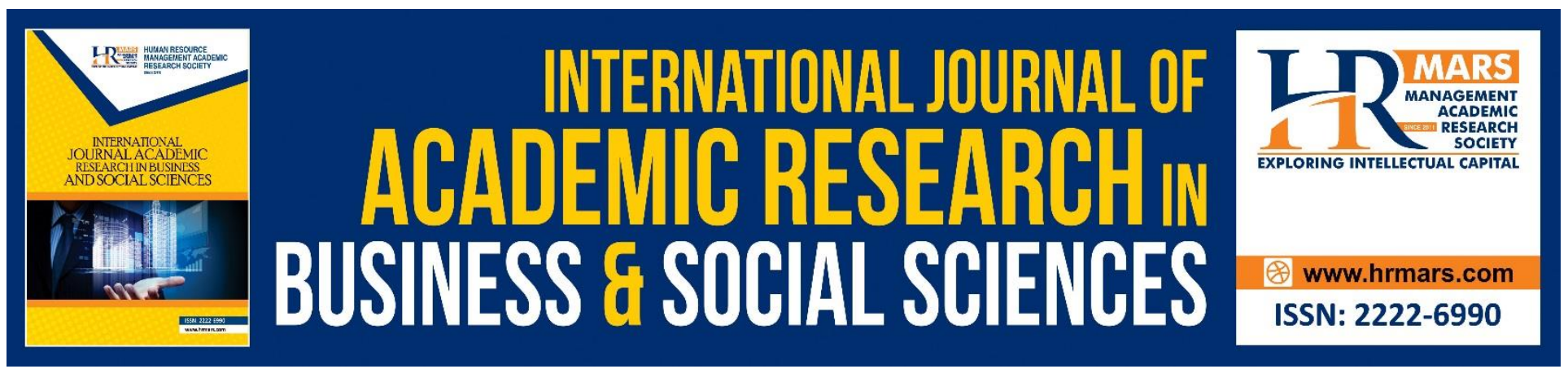

\title{
Influence of Project Supervision on Performance of Road Construction Projects, Uasin Gishu County
}

\author{
${ }^{1}$ Rachel Wangoi Kimingi, ${ }^{2}$ Dr. Jacob Olango \\ ${ }^{1}$ Master of Science in Project Management, ${ }^{2}$ Lecturer Jomo Kenyatta University of Agriculture and \\ Technology
}

\begin{abstract}
In Kenya, the number of public roads construction projects is increasing from time to time. However, it becomes difficult to complete projects in the allocated budget quality and timeframe. The main purpose of this study was to establish influence of project supervision on performance of road construction projects, Uasin Gishu County. The study was guided by the following objective; influence of project supervision on performance of road construction projects. The guiding theory was project management competency theory. A descriptive survey design was utilized in this study. The target population for this study was 108 respondents. The accessible population was 7 KURA engineers, 8 KERRA engineers, 10 KeNHA engineers, 13 County Roads Engineers, 23 supervisors and 47 contractors. This study used census method where all respondents was included in the study since the target population is small and manageable. Semi-structured questionnaires were used in this study to collect primary data from respondents. A pilot-test was conducted in Elgeyo Marakwet County where 10 questionnaires was issued out representing $10 \%$ of the population. Descriptive statistics was used to present the data inform of graphs and pie charts. Inferential statistics was used to show the relationships between the independent and dependent variable of the study. The analyzed data was presented using tables and charts. The study brought the supervision on performance of road construction projects budget and quality planned. There was significant relationship between project supervisions and performance of road construction projects $(\beta=.245$, $p<0.05)$. The study concluded that staffs should be supervised to ensure that they are doing work as per set goals and budget there is good supervision of project implementation to determine constrains of the completion of the project within time and quality.
\end{abstract}

Keywords: Performance, Project, Road Construction, Supervision, Influence

\section{Background of the Study}

Project supervision is the process of ensuring that the project is built in accordance with the requirements of the contract documents, approved plans, specifications, building codes, building code standards and applicable local codes and ordinances (Zhang, 2015). The project management system has experienced a long process of three systems. The first one is the unitary planned economy system; the second one is the binary model between owner and contractor; the third one is the 
INTERNATIONAL JOURNAL OF ACADEMIC RESEARCH IN BUSINESS AND SOCIAL SCIENCES Vol. 10, No. 11, 2020, E-ISSN: 2222-6990 @ 2020 HRMARS

currently used triangle model between owner, contractor and supervisor (Juliah, 2016). The introduction of the project supervision system is designed to form the equilibrium among the construction market participants (Zhang, Zhou, Zhuang \& Zhu, 2015).

The Canadian system have invested heavily in both project supervision and performance supervision as key tools to support accountability and results-based management (Pazvakavambwa \& Steyn, 2014). Additionally, the current state of the project supervision has evolved over time. The central designers have recognized that the development and implementation of supervision is long term and iterative therefore putting emphasis on the process of implementation as an important mechanism in itself in developing a supervision culture or results culture in an organization and across the entire system (Hunter \& Nielsen, 2013). Supervisions give the project implementers useful information about the status of the project as regards tentative and final evaluations (Shihemi, 2016).

In Botswana, the government plays a huge role by bringing the much-needed services to the communities in which they operate (Pienaar, Jarvis \& Larson, 2013). A lot of funds and other resources have been committed in the project of fight against poor road projects. The donors and other stakeholders expect transparency, proper accountability and project performance from them. This has demanded the use of M\&E tools to enhance transparency and accountability as well as demonstrate results. Additionally, the influence of the NGOs has greatly increased over the years. They currently participate officially in government working groups, policy making and serve as watchdog (Kensek \& Noble, 2014).

At the national level is MED, that provides leadership and coordinates the system by ensuring that two vital sources of M\&E information, namely Annual Progress Reports (APRs) on the Medium-Term Plan (MTP) of Vision 2030 and Annual Public Expenditure Review (PER) are ably and timely produced. At sub-national level, the District Development Officers, supervised by the Provincial Directors of Planning, were meant to produce the District Annual supervision and Evaluation Reports, (Mugo, 2014).

\section{Statement of the Problem}

Best practice requires that projects are supervised for control because stakeholders and public require transparency, accountability for resources used and its impact, worthy project performance and project team training and development of projects (Fazli, 2012). In Kenya, the number of public roads construction projects is increasing from time to time. However, it becomes difficult to complete projects in the allocated cost budget and timeframe (Waithera \& Susan, 2019). Similarly, for the few projects that get completed, they are associated with; scope creep, cost overruns, and poor workmanship or project time delays (Hassan, 2013). Consequently, arising from the creation of white elephant projects, huge resources are wasted, business opportunities lost, customers get dissatisfied and the overall development is retarded among others. The execution of these projects such GalanaGulalu Irrigation Scheme, SGR and KPC pipeline construction has however fallen off the set timelines triggering concerns over potential cost inflation. The public complained of delays, loss of public funds and luck of touch of what the populace is experiencing in order to pay tax which is misappropriated. Despite previous studies focusing on Ministry of Transport and Infrastructure and its associates, none has analysed the factors that affect the roads construction projects completion in Kenya with great detail on the supervision. The researcher is motivated to fill the knowledge gap by evaluating influence of project supervision on performance of road construction projects, Uasin Gishu County. 
INTERNATIONAL JOURNAL OF ACADEMIC RESEARCH IN BUSINESS AND SOCIAL SCIENCES

Vol. 10, No. 11, 2020, E-ISSN: 2222-6990 @ 2020 HRMARS

\section{Objective}

To establish influence of project supervision on performance of road construction projects, Uasin Gishu County.

\section{Research Hypothesis}

$\mathbf{H}_{0}$ : Project supervision has no statistical significance influence on performance of road construction projects, Uasin Gishu County.

\section{Literature Review}

This chapter looks at the theoretical framework, the conceptual framework and empirical review

\section{Theoretical Framework}

The study was guided by Project Management Competency Theory

\section{Project Management Competency Theory}

This theory was established by Mclelland and McBer in the 1980. The authors defined competency as the underlying characteristics of an individual that leads to attaining superior performance in a job or a situation (McClelland, \& McBer, 1980). The project supervision competency development framework defines competency as a cluster of related skills, knowledge, attitudes, and other personal traits that influences the way an individual undertakes a given task. Competency correlates with project performance and can be improved by means of training and development of manpower.

The theory assumes the role of project supervision competencies, supervision of development projects and effects of group dynamics in the performance of infrastructure projects. Gladder (2010) noted that technical project managers should be able to apply knowledge, skills, tools and techniques effectively so as to deliver as expected and be able to achieve the project's goals and optimize the integrated cost, schedule and effort. The study found out that two of the most influential standards; the PMBOK address only the knowledge aspect of competence while a third, Australian's National competency standards focuses on demonstrable performance. The study also found out that some project managers do not have the required competence skills to implement the road infrastructure projects.

According to this theory, application of traditional supervision approaches to road infrastructure projects is counter-productive. Hanisch \& Wald, (2012) argues that traditional supervision focuses on precise work breakdown structure, control rules, long term planning and rigid structures that can cause road projects to fail. Soderland et al., (2012) emphasizes that the project supervisor should possess project management competencies such as being able to; integrate various processes of the project, ability to meet the scope, time, cost and quality of the required project, manage and mitigate project risks and manage the physical and human resources involved in project implementation. The theory also focuses on the strategic approach used to deliver the road projects, contracting model employed, criteria of selecting the project supervisor, project contractor and project team and the tools assigned for delivering the project.

Project management competency theory has been criticized for its validity (Jamil, 2015). For it to be a truly useful tool, these criticisms and their roots must be critically analyzed to identify improvement measures. The approach suffers two limitations. Firstly, its frameworks tend to be bias towards achieving utilitarian objective whereby definition of competent managers is limited to their 
INTERNATIONAL JOURNAL OF ACADEMIC RESEARCH IN BUSINESS AND SOCIAL SCIENCES Vol. 10, No. 11, 2020, E-ISSN: 2222-6990 @ 2020 HRMARS

contribution to organizational economic performance. Secondly, its research was mainly conducted from the positivistic lenses which over-simply the complex nature of managerial work. Based on these findings, the author then proposes epistemological and ideological turns that researchers should consider in researching the competency subject (Al-Dhahabi \& Jacob, 2014).

\section{Empirical Review}

\section{Project Supervision and Road Construction Projects Performance}

Construction Project Supervision (CPS) is the process of ensuring that the project is built in accordance with the requirements of the contract documents, approved plans, specifications, building codes, building code standards and applicable local codes and ordinances. Good common practice is to establish a Project Manual or Project Procedures Manual prior to the commencement of the work so that all participants can utilize the same standards of practice, means and methods for diligence in the performance of their work (Lu, Ye, Flanagan \& Jewell, 2013).

Pal, Wang and Liang (2017) did a study on the critical factors in managing relationships in international engineering, procurement, and construction supervision of Chinese construction projects. Using a questionnaire to survey Chinese construction supervising engineers, this study concerns with the questions of how the engineers evaluate project success and to what extent key project stakeholders' performance correlates with project success. The results show that the engineers use relation among the key stakeholders as the most important criterion of project success while using the golden-triangle criteria; the stakeholders' project performance positively correlates with each other; project owners play the most important role in determining project success, and project management organizations' performance as the single point of project responsibility has significant correlations with project success criteria. The study however was done in China while my study is done in Kenya.

Santoso and Soeng (2016) analyzed the supervision and delay factors in road construction projects in Cambodia and their effects on project time, cost, and quality. A questionnaire survey was conducted with engineers from contractor and consultant firms in assessing the frequency and severity of delays so that an importance index for delay factors could be computed. In general, there was no significant difference between contractors and consultants in assessing the delay factors. The top-10 list was dominated by factors related to the contractor and the project. However, two external factors, rain and flood, were the first two factors on the list, which also had a high impact on the three project objectives. The study however never showed how supervision influences road construction performance.

Ondari, Gekara (2013) examined factors influencing successful completion of roads projects in Kenya. The study adopted a quantitative research approach based on survey conducted through questionnaires. It employed convenience sampling and the collected data was analyzed through correlation and percentages. The correlation tests showed the Pearsons coefficient for each variable was: management support 0.625 , design specifications 0.836 , contractors' capacity 0.567 while supervision capacity was 0.712 . The major findings were that there was significant relationship between all the independent variables and the dependent variable. However, the study focused on factors influencing successful completion of roads projects in Kenya as compared to my study Influence of project supervision on road construction.

Santoso and Soeng, (2016) did an analyzing delays of road construction projects in Cambodia: Causes and effects. A questionnaire survey was conducted with engineers from contractor and consultant 
INTERNATIONAL JOURNAL OF ACADEMIC RESEARCH IN BUSINESS AND SOCIAL SCIENCES Vol. 10, No. 11, 2020, E-ISSN: 2222-6990 @ 2020 HRMARS

firms in assessing the frequency and severity of delays so that an importance index for delay factors could be computed. In general, there was no significant difference between contractors and consultants in assessing the delay factors. The top-10 list was dominated by factors related to the contractor and the project. The remaining factors on the list were land acquisition, award of project to lowest bidder, equipment breakdowns, poor site arrangement, management and supervision, unexpected ground condition and terrain, low quality of the contractor human resources, late progress payments, and low productivity of labor. Nevertheless, the study took place Cambodia as compared to my study case in Uasin Gishu.

Zhao, Hwang and Lee, (2016) focused on about identifying critical leadership styles of project managers for green building projects in Singapores construction industry. Conducting a questionnaire survey with 30 project managers experienced in green construction. The results indicated that the leadership style of the project managers was more towards directive and task-oriented leadership but did not overlook their relationships with subordinates. However, the study focused on Identifying critical leadership styles of project managers for green building projects as compared to my study Influence of project supervision.

\section{Conceptual Framework}

The independent variable in this study was project supervision while dependent variable was project performance.

\begin{tabular}{|c|c|}
\hline $\begin{array}{cl}\text { Project Supervision } \\
\checkmark & \text { Staffs roles and responsibilities } \\
\checkmark & \text { Communications plan } \\
\checkmark & \text { Staffs capacity } \\
\checkmark & \text { Schedules } \\
\checkmark & \text { Plans }\end{array}$ & $\begin{array}{c}\text { Road Project Performance } \\
\checkmark \quad \text { Timely completion } \\
\checkmark \quad \text { Quality }\end{array}$ \\
\hline
\end{tabular}

Independent Variable

Dependent Variable

Figure 1 Conceptual Framework

\section{Research Methodology}

\section{Research Design}

A descriptive survey design was utilized in this study. This design was chosen because it is relatively quick and easy to conduct; data on all variables is only collected once. It is also good for descriptive analyses and for generating hypotheses. It is because the research design is a theory-based design method which is created by gathering, analyzing, and presenting collected data related to study variables within Uasin Gishu County. This allowed the researcher to provide insights into the why and how of research questions.

\section{Target Population}

The target population in this study constituted of officers from Kenya Urban Roads Authority, Kenya Rural Roads Authority, Kenya Highways Authority, County Government of Uasin Gishu Ministry of Roads, road supervisors and contractors from Uasin Gishu County. The target population for this study was 108 respondents. However, the accessible population was 7 KURA engineers, 8 KERRA 
INTERNATIONAL JOURNAL OF ACADEMIC RESEARCH IN BUSINESS AND SOCIAL SCIENCES

Vol. 10, No. 11, 2020, E-ISSN: 2222-6990 @ 2020 HRMARS

engineers, 10 KeNHA engineers, 13 County Roads Engineers, 23 supervisors and 47 contractors. Therefore, the total accessible population for this study were 108 respondents.

\section{Census}

This study adopted census method where all the respondents was included in the study since the target population is small and manageable while carrying out the study. Census was used because each member of the target population has an opportunity to provide the required information hence giving the study an elevated degree of statistical confidence in the study outcome. This implies all the 108 respondents were used in this study.

\section{Data Collection Instruments}

Semi-structured questionnaires were used in this study to collect primary data from respondents. The questionnaire was selected because it enabled the researcher to be consistent in asking questions and data yielded was easy to analyse. The questionnaires were formulated according to study objectives in a systematic procedure. The formulation of questionnaires was in six sections. Section A contained questions on demographic information of the respondents such as gender, age bracket, level of education, position held and work experience.

\section{Pilot Study}

A pilot-test was conducted in Elgeyo Marakwet County where 11 questionnaires was issued out representing $10 \%$ of the population (Maiyaki \& Mokhtar, 2011).

\section{Validity of Research Instruments}

The researcher focused on content validity, which refers to the accuracy with which an instrument measures the factors under study. Therefore, content validity was concerned with how accurately the questions asked tends to elicit the information being sought. The research instrument was tested for content validity by giving the questionnaire to the supervisors, and to engineer's staff experienced in the road constructions in the private sector.

\section{Reliability of Research Instruments}

In this study, reliability was determined by use of a pilot study and internal consistency technique. Test items was given to the pilot group to give suggestions for amendment (Sifuna, 2014). The test of reliability was calculated using the SPSS (Statistical Package for Social Science). Reliability was determined using Cronbach Alpha. The Cronbach's alpha coefficient values ranges between 0 and 1 (De Vaus, 2002). Higher alpha coefficient values mean that scales are more reliable. As a rule of thumb, acceptable alpha should be at least 0.70 or above (Hair et al., 2007).

\section{Data Processing and Analysis}

The completed questionnaires were tabulated and merged by use of the SPSS (Statistical Package for Social Sciences) Version 23 to analyse the data. Descriptive statistics was used to examine the characteristics of the population. Descriptive statistics was used in organizing and describing a set of data while excel were used to present the analysis in tables, graphs, pie charts, percentages, to give meaning to the responses. Multiple regression model is as indicated in equation 1. 
INTERNATIONAL JOURNAL OF ACADEMIC RESEARCH IN BUSINESS AND SOCIAL SCIENCES

Vol. 10, No. 11, 2020, E-ISSN: 2222-6990 @ 2020 HRMARS

Where;

Y represents road construction project performance (dependent variable)

$\boldsymbol{\beta}_{0}$ represents Constant (Coefficient of intercept)

$\mathbf{X}_{\mathbf{1}}$ represents project supervision

$\boldsymbol{\varepsilon}$ represents Error term

$\boldsymbol{\beta}_{1}$ represents regression coefficient of the four variables.

Beta is the probability of Type II error in any hypothesis test.

The test was conducted at $95 \%$ significant level to evaluate and make conclusion about the hypothesis.

\section{Findings and Discussions}

The population of the study consisted of officers from Kenya Urban Roads Authority, Kenya Rural Roads Authority, Kenya Highways Authority, County Government of Uasin Gishus Ministry of Roads, road supervisors and contractors from Uasin Gishu County. The results of response rate are presented in Table 1.

Table 1 Response Rate

\begin{tabular}{lll}
\hline Response Rate & Frequency & Percentage \\
\hline Responded & 81 & 75 \\
Not responded & 27 & 25 \\
Total & 108 & 100 \\
\hline
\end{tabular}

The response rate results in Table 1 revealed that 108 questionnaires were issued to the respondents however, 81 questionnaires were dully filled and returned. This translates to $75 \%$ response rate. This response rate is considered very good to enable the determination of the phenomenon that exist as it is in line with Mugenda and Mugenda (2008) assertion. They state that a response rate of above $70 \%$ is recommended for the generalization of the study findings. The high percentage of response rate was achieved through follow up of the data collection.

\section{Descriptive Analysis of the Study}

This section represents the descriptive statistics in relation to the study.

\section{Project Supervisions}

The study sought to examine the influence of project supervisions on performance of road construction projects, Uasin Gishu County. Table 2 presents the study results. 
INTERNATIONAL JOURNAL OF ACADEMIC RESEARCH IN BUSINESS AND SOCIAL SCIENCES Vol. 10, No. 11, 2020, E-ISSN: 2222-6990 @ 2020 HRMARS

Table 2 Project Supervisions

\begin{tabular}{|c|c|c|c|c|c|c|c|c|}
\hline \multicolumn{2}{|l|}{ Statements } & \multirow{2}{*}{$\frac{\text { SA }}{29}$} & \multirow{2}{*}{$\frac{A}{22}$} & \multirow{2}{*}{$\begin{array}{l}\text { UD } \\
8\end{array}$} & \multirow{2}{*}{$\begin{array}{l} \\
13\end{array}$} & \multirow{2}{*}{$\begin{array}{l}\text { SD } \\
9\end{array}$} & \multirow{2}{*}{$\begin{array}{l}\text { Mean } \\
3.60\end{array}$} & \multirow{2}{*}{$\begin{array}{l}\text { Std.Dev } \\
1.402\end{array}$} \\
\hline i. Staffs roles and responsibilities & $\mathrm{F}$ & & & & & & & \\
\hline $\begin{array}{l}\text { are monitored to ensure quality of } \\
\text { project to be completed }\end{array}$ & $\%$ & 35.8 & 27.2 & 9.9 & 16 & 11.1 & & \\
\hline ii. Communications plan ensure that & $\mathrm{F}$ & 18 & 39 & 7 & 10 & 7 & 3.62 & 1.209 \\
\hline $\begin{array}{l}\text { there is good supervision in } \\
\text { project implementation }\end{array}$ & $\%$ & 22.2 & 48.1 & 8.6 & 12.3 & 8.6 & & \\
\hline iii. Staffs capacity is the determinant & $\mathrm{F}$ & 24 & 39 & 8 & 6 & 4 & 3.90 & 1.068 \\
\hline of performance of road projects & $\%$ & 29.6 & 48.1 & 9.9 & 7.4 & 4.9 & & \\
\hline iv. Letter of completion assists know & $\mathrm{F}$ & 18 & 47 & 5 & 6 & 5 & 3.83 & 1.058 \\
\hline $\begin{array}{l}\text { the time used to compete the } \\
\text { projects and the amount used }\end{array}$ & $\%$ & 22.2 & 58 & 6.2 & 7.4 & 6.2 & & \\
\hline Valid N & 81 & & & & & & 3.74 & \\
\hline
\end{tabular}

Table 2 shows that $49(60.5 \%)$ of the respondents agreed with the statement that staffs roles and responsibilities are monitored to ensure quality of project to be completed. However, 22(27.2\%) of the respondents disagreed with the statement that staffs roles and responsibilities are monitored to ensure quality of project to be completed. Further the study findings showed in terms of means and standard deviation that staffs roles and responsibilities are monitored to ensure quality of project to be completed (Mean=3.60, Std. dev=1.402). Also, 57(70.4\%) of the respondents agreed with the statement that communications plan ensure that there is good supervision in project implementation. However, $17(20.9 \%)$ of the respondents disagreed with the statement that communications plan ensures that there is good supervision in project implementation.

Further the study findings showed in terms of means and standard deviation that Communications plan ensure that there is good supervision in project implementation (Mean=3.62, Std. dev=1.209). Further, $63(77.8 \%)$ of the respondents agreed with the statement that Staffs capacity is the determinant of performance of road projects. But, 10(12.3\%) of the respondents disagreed with the statement that Staffs capacity is the determinant of performance of road projects. Further the study findings showed in terms of means and standard deviation that Staffs capacity is the determinant of performance of road projects (Mean=3.90, Std. dev=1.068). Finally, 65(80.2\%) of the respondents agreed with the statement that letter of completion assists know the time used to compete the projects and the amount used.

However, $11(13.6 \%)$ of the respondents disagreed with the statement that letter of completion assists know the time used to compete the projects and the amount used. Further the study findings showed in terms of means and standard deviation that Letter of completion assists know the time used to compete the projects and the amount used (Mean=3.83, Std. dev=1.058). The study findings also reveal that project supervisions have a positive influence on performance of road construction projects, Uasin Gishu County. This implies that staffs roles and responsibilities are monitored to ensure quality of project to be completed. Also, communications plan ensures that there is good supervision in project implementation. Further, Staffs capacity is the determinant of performance of road projects. 
INTERNATIONAL JOURNAL OF ACADEMIC RESEARCH IN BUSINESS AND SOCIAL SCIENCES Vol. 10, No. 11, 2020, E-ISSN: 2222-6990 @ 2020 HRMARS

\section{Inferential Analysis}

This section puts across the relationship between independent variables and the dependent variable using both correlation and multiple regression analysis.

\section{Correlation Analysis}

Correlation refers to the strength of an association between two variables. A strong or high correlation means that two or more variables have a strong relationship with each other while a weak or low, correlation means that the variables are hardly related. Table 3 present the results.

Table 3 Correlation Analysis

\begin{tabular}{|l|l|l|l|}
\hline \multicolumn{2}{|l|}{} & Performance & Project Supervision \\
\hline Performance & Correlation & 1 & \\
\hline Project Supervision & Correlation & $.830^{* *}$ & 1 \\
\cline { 2 - 4 } & Sig. & 0.000 & \\
\hline
\end{tabular}

**. Correlation is significant at the 0.01 level (2-tailed).

The findings in Table 3 established that there exist a strong, positive and statistically $(r=0.830 ; p<$ 0.01) correlation between project supervisions and performance of road projects.

\section{Results for Multiple Regression Analysis}

The study examined the influence of project supervision on road construction projects performance in Uasin Gishu County using multiple regression analysis. The results are as follows;

\section{Model Summary}

The coefficient of determination $\left(R^{2}\right)$ and correlation coefficient $(R)$ shows the degree of association between supervision and road construction projects performance in Uasin Gishu County. The results are presented in Table 4.

Table 5 Multiple Regression Model Summary

\begin{tabular}{llll}
\hline $\mathbf{R}$ & R Square & Adjusted R Square & $\begin{array}{l}\text { Std. Error of the } \\
\text { Estimate }\end{array}$ \\
\hline $.909^{\mathrm{a}}$ & .826 & .817 & .33174 \\
\hline
\end{tabular}

The results of the regression in Table 4 indicate that $R^{2}=0.826$ and $R=0.909$. $R$ value gives an indication that there is a strong linear relationship between supervision and road construction projects performance in Uasin Gishu County. The $\mathrm{R}^{2}$ indicates that explanatory power of the independent variables is 0.826 . This means that about $82.6 \%$ of the variation in road construction projects performance is explained by the regression model. Adjusted $R^{2}$ is a modified version of $R^{2}$ that has been adjusted for the number of predictors in the model by less than chance. The adjusted $R^{2}$ of 0.817 which is slightly lower than the $R^{2}$ value. 
INTERNATIONAL JOURNAL OF ACADEMIC RESEARCH IN BUSINESS AND SOCIAL SCIENCES Vol. 10, No. 11, 2020, E-ISSN: 2222-6990 @ 2020 HRMARS

\section{Model Fitness}

The study determines the model fitness before using the regression model. The purpose of modeling is to find the best model that can represent the data. The study results were presented in Table 5.

Table 5 Model Fitness Results

\begin{tabular}{|c|c|c|c|c|c|}
\hline & $\begin{array}{l}\text { Sum } \\
\text { Squares }\end{array}$ & of $\mathbf{d f}$ & Mean Square & $\mathbf{F}$ & Sig. \\
\hline Regression & 39.633 & 4 & 9.908 & 90.031 & $.000^{\mathrm{b}}$ \\
\hline Residual & 8.364 & 76 & .110 & & \\
\hline Total & 47.997 & 80 & & & \\
\hline
\end{tabular}

From Table 5 the $\mathrm{F}$ test provides an overall test of significance of the fitted regression model. The $\mathrm{F}$ value indicates that all the variables in the equation are important hence the overall regression is significant.

The F-statistics produced $(F=90.03)$ was significant at $p=0.000$ thus confirming the fitness of the model and therefore. This implies that the multiple regression model was good fit for the data. Hence project supervisions influence performance of road construction projects therefore they should put emphasis on them.

\section{Regression Coefficients}

The study sought to establish the regression model coefficients in order to use in the regression equation. The study results are presented in Table 6.

Table 6 Significant Test Results for Overall Model

\begin{tabular}{llllll}
\hline & \multicolumn{2}{l}{$\begin{array}{l}\text { Unstandardized } \\
\text { Coefficients }\end{array}$} & \multicolumn{2}{l}{$\begin{array}{l}\text { Standardized } \\
\text { Coefficients }\end{array}$} \\
& B & Std. Error & Beta & & \\
& & & & t & Sig. \\
\hline (Constant) & .422 & .205 & & 2.058 & .043 \\
Project supervisions & .245 & .084 & .257 & 2.908 & .005 \\
\hline
\end{tabular}

The Table 6 indicates there was positive increase in project supervisions was found to have a positive and significant influence on performance of road construction projects $(\beta=.245, p=0.005)$. Thus, the regression equation becomes;

$Y=0.422+0.245 X_{1}$ Equation 2

Where:

Y represents performance of road projects, dependent variable $\mathbf{X}_{\mathbf{1}}$ represents project supervisions 
INTERNATIONAL JOURNAL OF ACADEMIC RESEARCH IN BUSINESS AND SOCIAL SCIENCES Vol. 10, No. 11, 2020, E-ISSN: 2222-6990 @ 2020 HRMARS

\section{Hypotheses Testing}

The regression results in Table 7 indicate that there is significant relationship between project supervisions and performance of road construction projects Uasin Gishu County $\left(\beta_{3}=.245, p<0.05\right)$. The study rejected the null hypothesis $\mathbf{H}_{01}$ : project supervisions have no statistical significance influence on performance of road construction projects, Uasin Gishu County.

Table 7 Summary of Hypotheses Test Results

\begin{tabular}{|l|l|l|}
\hline Hypothesis & $\beta, p$-value & Decision \\
\hline $\mathrm{H}_{01}$ Project supervision has no statistical significance & $\beta=.245, p<0.05$ & $\mathbf{H}_{01}$ was rejected \\
influence on performance of road construction \\
projects, Uasin Gishu County.
\end{tabular}

\section{Conclusions And Recommendation}

This allows the supervisors to monitor the project progress against resource allocated in order to ensure quality and timely completion of projects. The study further concluded that project supervisions has a positive influence on performance of road construction projects, Uasin Gishu County. Project supervisions carried out in the road construction projects ensure quality of project to be completed within stipulated time and budget. Staffs are supervised to ensure that they are doing work as per set goals and budget. There is good supervision of project implementation to determine constrains of the completion of the project within time and quality.

The study recommends that project supervisions should be carried out with aim of achieving the project goals and avoid project delay. Understanding the needs and interests of each staffs helps the supervisors to set up a good working environment that motivates employees leading to an increased performance. The ministry of roads officers is recommended to gain insight on the significant role played by monitoring and evaluation on government development projects. This would enable policy makers in formulating and implementing measures that would enhance efficient monitoring and evaluation and evaluation of government projects and achieve success in project performance in an effort to achieve better development and achieve vision 2030.

\section{References}

Al-Dhahabi, G. A., \& Jacob, A. A. (2014). Strengthening the Competence of the Accounting Profession According to the New Iraqi Environment with the Help of International Experiences. The Arab Organization for Administrative Development, 3(2), 200-220.

Gladder, A. (2010). Learning and Competence Development, Review of Economics and Statistics, 49(2), 92-107.

Hanisch, B., \& Wald, A. (2012). A Bibliometric View on the Use of Contingency Theory in Project Management Research. Project Management Journal, 43(3), 4-23.

Hassan, A. I. (2013). An Investigation of Structural Capacity as a Component of Monitoring and Evaluation and Evaluation in Project Success of Road Construction Projects in Kenya. International Journal of Academic Research in Business and Social Sciences, 3(8), 443-450.

Jamil, R. (2015). What is Wrong with Competency Research? Two Propositions. Asian Social Science, 11(26), 43-50 
INTERNATIONAL JOURNAL OF ACADEMIC RESEARCH IN BUSINESS AND SOCIAL SCIENCES

Vol. 10, No. 11, 2020, E-ISSN: 2222-6990 @ 2020 HRMARS

Lu, W., Ye, K., Flanagan, R., \& Jewell, C. (2013). Developing Construction Professional Services in the International Market: SWOT Analysis of China. Journal of Management in Engineering, 29(3), 302-313.

Mcclelland, S., \& Mcber, N. (1980). Project Management Competency Theory. International Journal of Project Management, 19(2), 393-419

Ondari, P. O., \& Gekara, J. M. (2013). Factors Influencing Successful Completion of Roads Projects in Kenya. International Journal of Social Sciences and Entrepreneurship, 1(6), 26-48.

Pazvakavambwa, A., \& Steyn, G. M. (2014). Implementing Results-Based Management in The Public Sector of Developing Countries: what Should be Considered? Mediterranean Journal of Social Sciences, 5(20), 245.

Pienaar, E. F., Jarvis, L. S., \& Larson, D. M. (2013). Creating Direct Incentives for Wildlife Conservation in Community-Based Natural Resource Management Programmes in Botswana. The Journal of Development Studies, 49(3), 315-333.

Santoso, D. S., \& Soeng, S. (2016). Analyzing Delays of Road Construction Projects in Cambodia: Causes and Effects. Journal of Management in Engineering, 32(6), 20-30.

Waithera, K. B., \& Susan, W. E. R. E. (2019). Factors Affecting Cost Overruns in Construction Projects a Case of Kenya National Highways Authority. International Journal of Business Management and Finance, 1(1), 500-520.

Zhang, R., Zhou, Y., Zhuang, H., \& Zhu, X. (2015). Study on the Project Supervision System Based on The Principal-Agent Theory. Journal of Industrial Engineering and Management, 8(2), 491508.

Zhao, X., Hwang, B. G., \& Lee, H. N. (2016). Identifying Critical Leadership Styles of Project Managers for Green Building Projects. International Journal of Construction Management, 16(2), 150160. 